Doi: HTTPS://DOI.ORG/10.23910/IJBSM/2017.8.1.1797a

\title{
Impact of Timber Harvesting on Vegetation in the Ural Mountains
}

\author{
Natalya Ivanova* and Ekaterina Zolotova
}

Botanical Garden Ural Branch of Russian Academy of Sciences, 202a, 8-March street, Yekaterinburg (620 130), Russia

\section{Corresponding Author}

Natalya Ivanova

e-mail: i.n.s@bk.ru

\author{
Article History \\ Manuscript No. AR1797a \\ Received in $28^{\text {th }}$ Jan, 2017 \\ Received in revised form $7^{\text {th }}$ Feb, 2017 \\ Accepted in final form $7^{\text {th }}$ Feb, 2017
}

\begin{abstract}
Transformation of vegetation, which takes place in dark-coniferous forests under the action of clear timber harvesting in dominating forest habitats of the mountains of the Middle Urals, Russia, was studied. Harvesting was conducted 65 years ago. Research objects were 190-year-old spruce forests with domination in herbaceous layer of Oxalis acetosella L., 65-year-old birch forest with undergrowth of thick spruce, 65-year-old birch forest with undergrowth of sparse spruce and hay meadow. The plots were studied with regard to tree stand, understory and grass layer. Sample plots included no less than 200 woody plants. The undergrowth of trees on the tapes $20 \times 4 \mathrm{~m}^{2}$ was studied. In order to determine the productivity of grass-dwarf shrub layer 10 to 20 record subplots of $1 \times 1$ m² over period of maximum grass stand were established. The plants were cut at soil level, sorted by species, dried to an absolutely dry condition at the temperature of $105^{\circ} \mathrm{C}$ and afterwards weighed. It was found that strong anthropogenic effects lead to appearance of a wide spectrum of vegetation communities within a single forest habitat (one type of indigenous forests). For a long time these vegetation communities differ by the structure of all vegetation layers, conditions of soil formation, and, consequently, by the direction and intensity of restoration processes. Age of spruce undergrowth was 65 years or more for most of the recorded trees. This undergrowth survived during harvesting. The reforestation direction was determined by the number of spruce undergrowth, which was stored in the timber harvesting.
\end{abstract}

Keywords: Forest, timber harvesting, vegetation, Ural mountains, Russia

\section{Introduction}

The problem of biodiversity is becoming very relevant due to the increase in the rate of transformation of natural ecosystems (Noss, 1999; Zobel, 2016). Large-scale reduction of natural ecosystems will inevitably lead to a decrease in their regulatory powers and the destruction of the planet's biodiversity (Pavlov et al., 2010). In the past, the consequences of anthropogenic disturbance of ecosystems led only to locally or regionally environmental damages; presently, however, a global scale of this process is becoming more apparent (Foley et al., 2005; Chen et al., 2011; Westgate et al., 2013). Timber harvesting is a major factor in the transformation of structure and function forest ecosystem. The huge scale of timber harvesting in various countries is the cause of global effects (Achard et al., 2006; Young et al., 2006). Detailed quantitative studies are needed to further advance theoretical foundations of the concept of sustainable forest management (Maiti et al., 2016).

More than $20 \%$ of the world's forest ecosystems are in Russia. They are of paramount importance to maintain the stability of the biosphere (Global Biodiversity Outlook, 2006). In the Ural Mountains region of Russia, industrial logging has been carried out for approximately 300 years. Intensive cutting and other forms of industrial disturbance of the mountain forests have brought about a highly mosaic structure of vegetation represented by various types of forests at different stages of regeneration and age succession (Shirokikh et al., 2013; Ivanova, 2014).

Numerous studies were carried out in connection with the problem of reforestation on clear-cuts. Reforestation features in Western and Central Europe, in Scandinavia and Canada are considered in numerous publications (Thomasius, 1990; Fitzsimmons, 2003; Ibbe et al., 2011; Gray and Hamann, 2011; Fisichelli et al., 2014). Much attention is paid to this problem in Russia (Melehov, 1933; Pobedinskiy, 1966; Sannikov, 2004; Davydychev, 2006). However a lot of questions have not been decided by this day (Ivanova, 2012; Gauthier et al., 2015; Lankin and Ivanova, 2015; Cusack et al., 2016; Kuuluvainen, 2016). Regional features of the manifestation of this global process are not determined until.

\section{Research Area}

The research area is located in the Ural Mountains, Russia. 
The Ural Mountains are located on the border between Europe and Asia, at the junction of two floras. Ural forests (Russia) are part of the belt of coniferous forests in the Northern Hemisphere. They are one of the 200 hot spots of biodiversity, the preservation of which is necessary for the future survival of mankind on the planet Earth. The research site is situated in the Zauralsky (Trans-Ural) hilly piedmont province (Middle Ural, Russia) between $57^{\circ} 00^{\prime}-57^{\circ} 05^{\prime} \mathrm{N}$; $60^{\circ} 15^{\prime}-60^{\circ} 25^{\prime} \mathrm{E}$. It is divided in foothills formed by the alternation of meridian heights and ridges (Kolesnikov et al., 1973). Absolute heights are 200-500 m amsl. The climate is temperately cold, temperately damp. A frostless period lasts from 90 to 115 days, average annual temperature is $+1{ }^{\circ} \mathrm{C}$, and the average snowfall is between 40 and $50 \mathrm{~cm}$ (Kolesnikov et al., 1973).

\section{Research Objects}

Test sites were located in similar geomorphological elements, namely at the bottom of draining gentle slopes, which represent the most widely occurring group of forest conditions. Stable fresh loamy soils are formed on gruss eluvium-talus deposits of crystalline rocks. As a result, podsolization and gleying processes are limited and browntype soils become more frequent in these forest conditions (Firsova, 1977). Dark coniferous forests are indigenous to these conditions (Figure 1). The study was classified by use of spruce forests as Vaccinio-Piceetea class (boreal dark coniferous and light coniferous forests), as Piceion exelsa union (mesophytic coniferous forests with dominance in the tree layer of Picea obovata Ledeb.), as Melico-Piceenion subunion. The dominant herbaceous layer is Oxalis acetosella $\mathrm{L}$. We studied the vegetation transformation after timber harvesting in these forests. Harvesting was conducted 65 years ago. The study was carried out in the spruce forest (Figure 1), birch forest with undergrowth of thick spruce (Figure 2), birch forest with undergrowth of sparse spruce (Figure 3 ) and hay meadow (Figure 2, 4). Hay meadows are anthropogenic in origin and their existence is supported by mowing.

\section{Sampling Procedures}

The work was based on the methodological approach of geogenetic (geodynamical) forest typology (Ivanova, Zolotova, 2014). A geo-genetic classification is a classification based on forest origin and evolution patterns which take into account all of the developmental stages of the forest ecosystem and can be used to predict their future changes. B.P. Kolesnikov and his colleagues (Kolesnikov et al., 1973) published a fundamental work on typology of the Sverdlovsk region forest which is still used both for scientific purposes and forestry. However, differences in the composition of plants and soils in different forest types, especially in sub-mountain and mountain areas remained little studied until very recently. This lacuna had been filled by the present study (Ivanova, 2012a; Ivanova, Zolotova, 2013a, 2013b, 2015). These studies were the basis for this study.

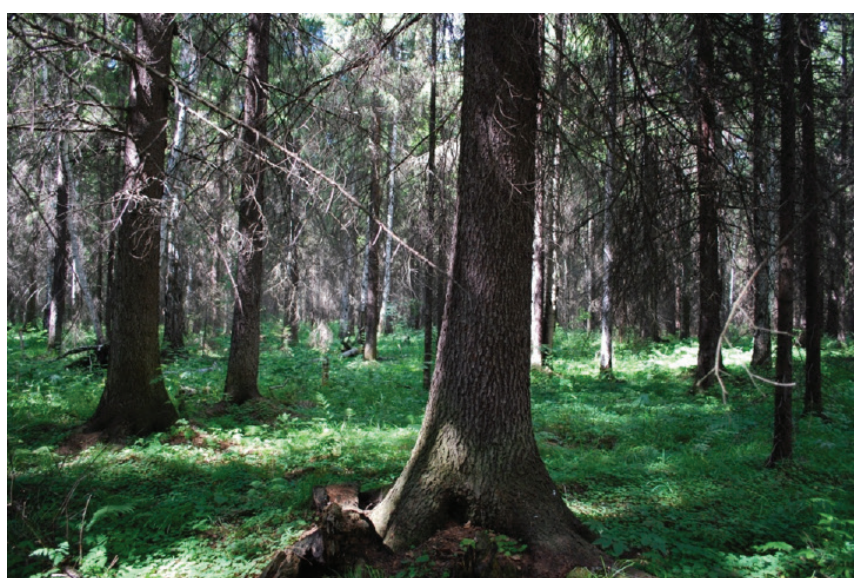

Figure 1: Indigenous spruce forest with Oxalis acetosella in the Ural mountains under study

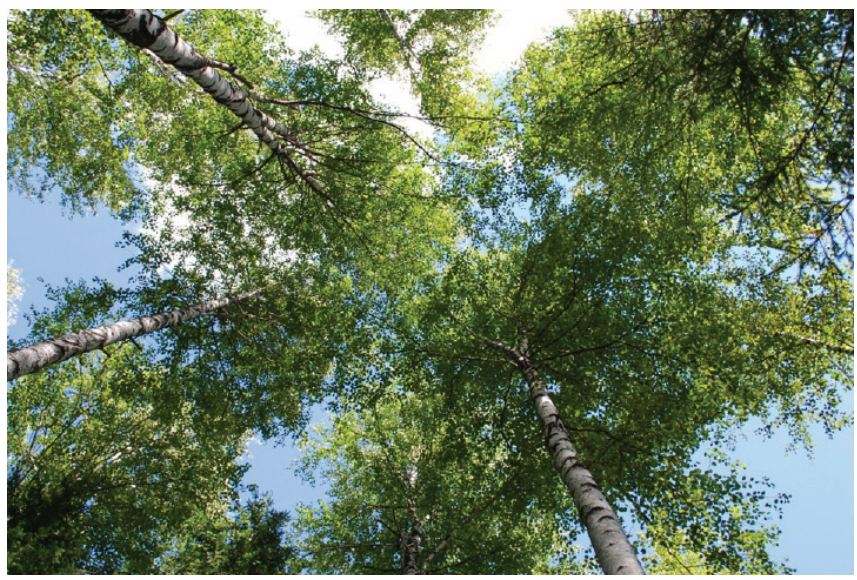

Figure 2: The foreground photo depicts a meadow, which was formed on the site of the spruce forest after felling with birch forest - in the background under study

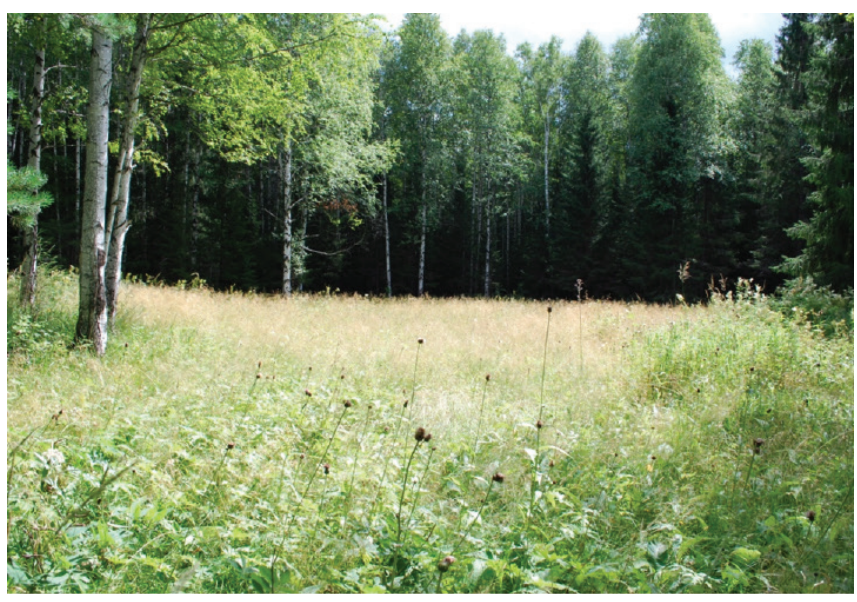

Figure 3: Birch forest with undergrowth of sparse spruce in the Ural mountains under study 


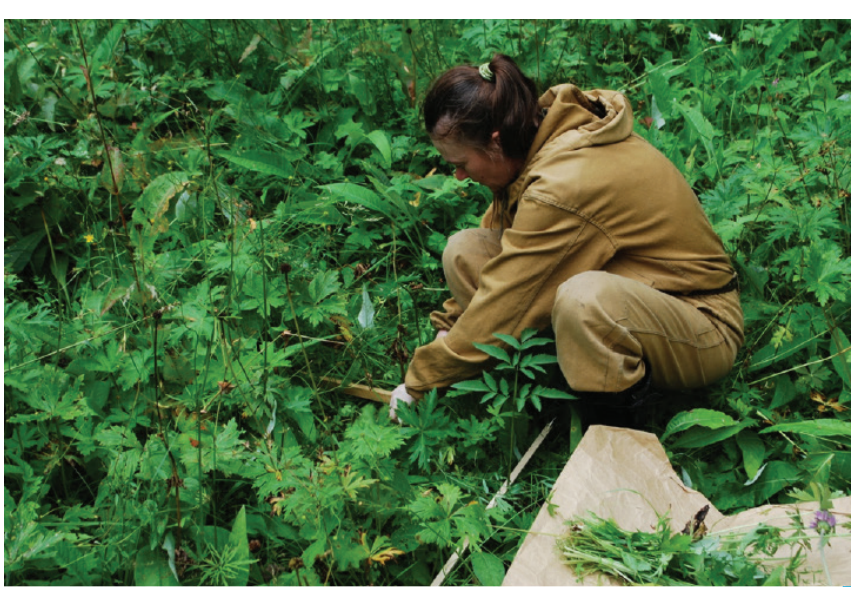

Figure 4: Study of the productivity of herbaceous layer in the meadow, which was formed on the site of the spruce forest after harvesting

The $0.2-0.5$ ha sample plots were laid according to commonly used methods (Forest Communities Study Methods, 2002). Sample plots included no less than 200 woody plants. The plots were studied with regard to their tree stand, understory, and grass layer. All the trees on the sampling plot were counted, their diameter and height were also measured. The age by the annual rings was identified. The undergrowth of trees on the tapes $20 \times 4 \mathrm{~m}^{2}$, which had been divided into $2 \times 2 \mathrm{~m}^{2}$ subplots was studied. For characteristic shrubs, the projective cover was defined. Totally dry biomass as an integral role of plants was taken. In order to determine the productivity of grass-dwarf shrub layer, 10 to 20 record subplots of $1 \times 1 \mathrm{~m}^{2}$ over period of maximum grass stand (July) were established. The subplots were situated on two perpendicular lines. The plants were cut at soil level, sorted by species, dried to an absolutely dry condition at the temperature of $105^{\circ} \mathrm{C}$ and afterwards weighed.

\section{Results and Discussion}

Timber harvesting caused changes in structure of vegetation communities: the species composition and gross productivity of lower layers. The structure of the stand, the undergrowth of woody plants and the herbaceous layer are shown in Table 1 . The quantitative ratio of species was altered most (Table 2). The correlation coefficients are shown in

\begin{tabular}{|c|c|c|c|c|}
\hline Structural parameters & Spruce forest & $\begin{array}{l}\text { Birch forest with } \\
\text { undergrowth of thick } \\
\text { spruce }\end{array}$ & $\begin{array}{c}\text { Birch forest with } \\
\text { undergrowth of } \\
\text { sparse spruce } \\
\end{array}$ & Hay meadow \\
\hline \multicolumn{5}{|l|}{ Tree stand } \\
\hline Age, years & 190 & 65 & 65 & - \\
\hline Mean height, $\mathrm{m}$ & 26 & 24 & 20 & - \\
\hline \multicolumn{5}{|l|}{ Soil } \\
\hline Name & $\begin{array}{l}\text { mountain- } \\
\text { forest brown }\end{array}$ & $\begin{array}{l}\text { mountain-forest } \\
\text { podsolized brown }\end{array}$ & $\begin{array}{c}\text { mountain-forest } \\
\text { brown }\end{array}$ & $\begin{array}{l}\text { meadow-forest turf } \\
\text { pale-yellow podsolic }\end{array}$ \\
\hline Forest litter capacity of, sm & 4 & 2 & 2 & 2 \\
\hline Soil capacity, sm & 120 & 95 & 150 & 95-100 \\
\hline \multicolumn{5}{|l|}{ Undergrowth of Picea obovata } \\
\hline No., thousands units ha-1 & + & 4.0 & 0.5 & + \\
\hline Predominant height, m & $0.1-0.5$ & $5-10$ & $2-7$ & - \\
\hline \multicolumn{5}{|l|}{ Undergrowth of Pinus sylvestris } \\
\hline No., thousands units ha-1 & - & - & - & + \\
\hline Predominant height, $\mathrm{m}$ & - & - & - & $0.1-0.3$ \\
\hline \multicolumn{5}{|l|}{ Lower layer (herb layer) } \\
\hline Species, total & 23 & 21 & 44 & 55 \\
\hline $\begin{array}{l}\text { Projective cover/coefficient } \\
\text { of variation, } \%\end{array}$ & $\begin{array}{l}21.0 \\
26.6\end{array}$ & $\begin{array}{l}14.4 \\
56.9\end{array}$ & $\begin{array}{l}66.3 \\
27.5\end{array}$ & $\begin{array}{l}100 \\
19.5\end{array}$ \\
\hline Average height, $\mathrm{cm}$ & 7 & 7 & 47.9 & 60 \\
\hline $\begin{array}{l}\text { Aboveground biomass }\left(\mathrm{g}^{-2} \text { in }\right. \\
\text { absolutely dry state)/coef- } \\
\text { ficient of variation, } \%\end{array}$ & $\begin{array}{l}17.7 \\
33.2\end{array}$ & $\begin{array}{l}4.4 \\
66.2\end{array}$ & $\begin{array}{c}100.9 \\
7.0\end{array}$ & $\begin{array}{c}280.6 \\
7.7\end{array}$ \\
\hline
\end{tabular}


Table 2: Dominant change and biomass dynamics of species of herbaceous layer

\begin{tabular}{|c|c|c|c|c|c|c|c|c|}
\hline \multirow[t]{2}{*}{ Species } & \multicolumn{2}{|c|}{ Spruce forest } & \multicolumn{2}{|c|}{$\begin{array}{c}\text { Birch forest with } \\
\text { undergrowth of thick } \\
\text { spruce }\end{array}$} & \multicolumn{2}{|c|}{$\begin{array}{c}\text { Birch forest with } \\
\text { undergrowth of } \\
\text { sparse spruce }\end{array}$} & \multicolumn{2}{|c|}{ Hay meadow } \\
\hline & A & $\mathrm{B}$ & A & $\mathrm{B}$ & A & $\mathrm{B}$ & A & $\mathrm{B}$ \\
\hline Oxalis acetosella L. & 8.07 & 16.5 & 1.7 & 4.4 & 0.28 & 0.6 & - & - \\
\hline Calamagrostis arundinacea (L.) Roth & 1.16 & 4.9 & 0.41 & 0.8 & 55.18 & 67.9 & - & - \\
\hline Gymnocarpium dryopteris (L.) Newm. & 1.65 & 14.4 & 0.04 & 0.3 & - & - & - & - \\
\hline Fragaria vesca $\mathrm{L}$. & 0.42 & 1.8 & 0.38 & 2.2 & 0.51 & 1.1 & - & - \\
\hline Asarum europaeum L. & 0.72 & 4.1 & 0.08 & 0.2 & 0.33 & 1.3 & - & - \\
\hline Rubus saxatilis L. & 0.53 & 5.4 & - & - & - & - & 0.03 & 0.1 \\
\hline Athyrium filix-femina (L.) Roth & 0.75 & 5.5 & - & - & 0.6 & 3.6 & - & - \\
\hline Linnaea borealis L. & 0.16 & 1.3 & - & - & 0.55 & 1.6 & 0.22 & 0.6 \\
\hline Maianthemum bifolium (L.) F. W. Schmidt & 0.45 & 1.4 & 0.24 & 1.4 & 0.48 & 1.2 & 0.1 & 0.3 \\
\hline Aegopodium podagraria L. & 0.31 & 1.7 & - & - & 6.78 & 9.9 & - & - \\
\hline Viola selkirkii & 0.62 & 2.9 & - & - & 0.02 & 0.05 & - & - \\
\hline Equisetum sylvaticum L. & 0.33 & 1.4 & - & - & - & - & - & - \\
\hline Cerastium pauciflorum Stev. ex Ser. & 0.59 & 2.7 & 0.4 & 0.8 & 1.17 & 1.9 & - & - \\
\hline Dryopteris expansa L. & 0.17 & 1.9 & 0.12 & 0.8 & - & - & - & - \\
\hline Luzula pilosa (L.) Willd. & 0.11 & 0.7 & 0.26 & 0.7 & 0.03 & 0.2 & 0.8 & 2.3 \\
\hline Pyrola rotundifolia $\mathrm{L}$. & 0.06 & 1.4 & 0.47 & 3 & 0.02 & 0.1 & - & - \\
\hline Stellaria holostea $\mathrm{L}$. & 0.23 & 1.5 & 0.11 & 0.7 & 2.1 & 4.4 & - & - \\
\hline Aconitum septentrionale Koelle & - & - & - & - & 4.67 & 14.1 & - & - \\
\hline Cirsium heterophyllum (L.) Hill & - & - & - & - & 0.88 & 2.8 & 39.43 & 65.4 \\
\hline Thalictrum minus L. & 0.05 & 1.1 & - & - & 3.13 & 8.1 & - & - \\
\hline Geranium sylvaticum L. & 0.15 & 2.7 & - & - & 5.67 & 10.5 & 11.77 & 27.6 \\
\hline Pulmonaria mollis Wulf. & 0.05 & 1.1 & 0.03 & 0.1 & 3.09 & 7.0 & - & - \\
\hline Carex nigra (L.) Reichard & 0.23 & 1.5 & 0.01 & 0.05 & 9.47 & 20.9 & 0,03 & 0.05 \\
\hline Lathyrus vernus (L.) Bernh. & 0.04 & 0.4 & 0.04 & 0.2 & 1.28 & 2.8 & 0.02 & 0.05 \\
\hline Vicia sepium L. & - & - & - & - & 1.0 & 2.4 & 0.83 & 1.5 \\
\hline Senecio nemorensis L. & - & - & - & - & 1.37 & 3.8 & - & - \\
\hline Deschampsia cespitosa (L.) Beauv. & 0.04 & 1.0 & - & - & - & - & 23.97 & 26.9 \\
\hline Bistorta carnea (C. Koch) Kom. & - & - & - & - & - & - & 30.97 & 47.7 \\
\hline Carex pallescens L. & - & - & - & - & - & - & 21.97 & 28.0 \\
\hline Carex leporina $\mathrm{L}$. & - & - & - & - & - & - & 9.73 & 23.2 \\
\hline Agrostis tenuis SIBTH. & - & - & - & - & - & - & 34.03 & 48.5 \\
\hline Alchemilla vulgaris $\mathrm{L}$. & - & - & - & - & - & - & 19.67 & 26.6 \\
\hline Filipendula ulmaria (L.) Maxim. & - & - & - & - & - & - & 29.8 & 84.5 \\
\hline Trollius europaeus L. & 0.01 & 0.3 & - & - & - & - & 8.70 & 15.3 \\
\hline Ranunculus auricomus L. & - & - & - & - & - & - & 12.37 & 17.2 \\
\hline Myosotis L. & - & - & - & - & - & - & 6.60 & 10.7 \\
\hline
\end{tabular}

A: Average aboveground biomass ( $\mathrm{g}^{-2}$ in absolutely dry state); B: Maximum above ground biomass $\left(\mathrm{g}^{-2}\right.$ in absolutely dry state); "“": species is not found 
Table 3. Species forming the main background of lower layers in spruce forests (Oxalis acetosella, Gymnocarpium dryopteris, Asarum europaeum, Fragaria vesca, Equisetum sylvaticum, Dryopteris expansa, Viola selkirkii) lost sharply in their biomass in secondary birch forests and were absent altogether in meadows. Some species are

\begin{tabular}{|c|c|c|c|c|c|c|c|c|}
\hline \multirow[t]{2}{*}{ Species } & \multicolumn{2}{|c|}{ Spruce forest } & \multicolumn{2}{|c|}{$\begin{array}{l}\text { Birch forest with } \\
\text { undergrowth of thick } \\
\text { spruce }\end{array}$} & \multicolumn{2}{|c|}{$\begin{array}{l}\text { Birch forest with } \\
\text { undergrowth of } \\
\text { sparse spruce }\end{array}$} & \multicolumn{2}{|c|}{ Hay meadow } \\
\hline & $\mathrm{A}$ & B & A & B & A & B & A & B \\
\hline Oxalis acetosella $\mathrm{L}$. & 54 & 83.0 & 84.3 & - & 0.28 & 0.6 & - & - \\
\hline Calamagrostis arundinacea (L.) Roth & 123.7 & 176.6 & 18.4 & - & 55.18 & 67.9 & - & - \\
\hline Gymnocarpium dryopteris (L.) Newm. & 226.0 & 264.6 & - & - & - & - & - & - \\
\hline Fragaria vesca $\mathrm{L}$. & 142.2 & 212.9 & 95.2 & - & 0.51 & 1.1 & - & - \\
\hline Asarum europaeum L. & 174.7 & 115.4 & 153.2 & - & 0.33 & 1.3 & - & - \\
\hline Rubus saxatilis $\mathrm{L}$. & 240.7 & - & - & 173.2 & - & - & 0.03 & 0.1 \\
\hline Athyrium filix-femina (L.) Roth & 216.1 & - & 244.9 & - & 0.6 & 3.6 & - & - \\
\hline Linnaea borealis L. & 206.4 & - & 120.5 & 153.7 & 0.55 & 1.6 & 0.22 & 0.6 \\
\hline Maianthemum bifolium (L.) F. W. Schmidt & 94.3 & 218.3 & 83.9 & 173.2 & 0.48 & 1.2 & 0.1 & 0.3 \\
\hline Aegopodium podagraria $\mathrm{L}$. & 161.9 & - & 56.9 & - & 6.78 & 9.9 & - & - \\
\hline Viola selkirkii & 144.8 & - & 118.3 & - & 0.02 & 0.05 & - & - \\
\hline Equisetum sylvaticum L. & 148.3 & - & - & - & - & - & - & - \\
\hline Cerastium pauciflorum Stev. ex Ser. & 118.8 & 124.2 & 60.8 & - & 1.17 & 1.9 & - & - \\
\hline Dryopteris expansa L. & 294.0 & 246.9 & - & - & - & - & - & - \\
\hline Luzula pilosa (L.) Willd. & 192.0 & 101.7 & 244.9 & 162.5 & 0.03 & 0.2 & 0.8 & 2.3 \\
\hline Pyrola rotundifolia $\mathrm{L}$. & 479.6 & 237.7 & 244.9 & - & 0.02 & 0.1 & - & - \\
\hline Stellaria holostea L. & 188.2 & 244.6 & 68.1 & - & 2.1 & 4.4 & - & - \\
\hline Aconitum septentrionale Koelle & - & - & 132.6 & - & 4.67 & 14.1 & - & - \\
\hline Cirsium heterophyllum (L.) Hill & - & - & 125.3 & 78.29 & 0.88 & 2.8 & 39.43 & 65.4 \\
\hline Thalictrum minus L. & 479.6 & - & 114.7 & - & 3.13 & 8.1 & - & - \\
\hline Geranium sylvaticum L. & 226.0 & - & 67.8 & 119.6 & 5.67 & 10.5 & 11.77 & 27.6 \\
\hline Pulmonaria mollis Wulf. & 479.6 & 170.8 & 87.4 & - & 3.09 & 7.0 & - & - \\
\hline Carex nigra (L.) Reichard & 200.1 & 264.6 & 74.6 & 86.6 & 9.47 & 20.9 & 0,03 & 0.05 \\
\hline Lathyrus vernus (L.) Bernh. & 248.4 & 196.6 & 91.1 & 173.2 & 1.28 & 2.8 & 0.02 & 0.05 \\
\hline Vicia sepium L. & - & - & 110.6 & 91.7 & 1.0 & 2.4 & 0.83 & 1.5 \\
\hline Senecio nemorensis L. & - & - & 144.1 & - & 1.37 & 3.8 & - & - \\
\hline Deschampsia cespitosa (L.) Beauv. & 479.6 & - & - & 12.8 & - & - & 23.97 & 26.9 \\
\hline Bistorta carnea (C. Koch) Kom. & - & - & - & 73.4 & - & - & 30.97 & 47.7 \\
\hline Carex pallescens $\mathrm{L}$. & - & - & - & 41.8 & - & - & 21.97 & 28.0 \\
\hline Carex leporina $\mathrm{L}$. & - & - & - & 120.1 & - & - & 9.73 & 23.2 \\
\hline Agrostis tenuis SIBTH. & - & - & - & 36.8 & - & - & 34.03 & 48.5 \\
\hline Alchemilla vulgaris $\mathrm{L}$. & - & - & - & 33.3 & - & - & 19.67 & 26.6 \\
\hline Filipendula ulmaria (L.) Maxim. & - & - & - & 159.2 & - & - & 29.8 & 84.5 \\
\hline Trollius europaeus L. & 479.6 & - & - & 71.7 & - & - & 8.70 & 15.3 \\
\hline Ranunculus auricomus L. & - & - & - & 34.3 & - & - & 12.37 & 17.2 \\
\hline Myosotis L. & - & - & - & 53.9 & - & - & 6.60 & 10.7 \\
\hline
\end{tabular}


present in small amounts in forest, but is dominated in secondary ecosystems. Calamagrostis arundinacea, Carex nigra, Aegopodium podagraria, Aconitum septentrionale, Pulmonaria mollis, Lathyrus vernus dominated under the canopy of birch forests. Cirsium heterophyllum, Trollius europaeus, Deschampsia caespitosa, Bistorta carnea, Alchemilla vulgaris, Filipendula ulmaria, Ranunculus auricomus and Agrostis tenuis dominated in hay meadows. Hay meadows were also distinguished for largest floristic diversity (55 species of vascular plants). The aboveground biomass increased. The aboveground biomass decreased only under the canopy of birch forests with undergrowth of thick spruce. Fellings in spruce forests of the Middle Ural region did not alter the type of soil formation in short-term derivative birch forests (Zubareva, Firsova, 1963; Ivanova et al., 2000). These plant communities were characterized by brown mountain-forest soils (Ivanova, Zolotova, 2011; Zolotova, 2013).

Previously, studies in the Southern Urals had been conducted. Indigenous and secondary forests, forest succession dynamics after timber harvesting, conjugacy of dynamics in forest layers and individual species in the succession series were studied (Ivanova, 2000, 2012b, 2014). Similar results, such as for the Middle Urals were obtained. Succession dynamic trend were not uniform for the stand or subordinate layers. Within a single natural forest, a whole range of alternative succession series were formed-spruce forests, fir forests, birch forests, and aspen forests (short-term, long-term, and stable-term secondary). The dynamics of the stand and subordinate layers differed in the succession series, with the differences remaining for a considerable time period.

The age of the young spruce trees in the birch forests of Middle Urals was determined. Age of spruce undergrowth was 65 years or more for most of the recorded trees. That is, spruce undergrowth appeared in the spruce forests, and it survived during harvesting. Young spruce was found in small quantities. Status of spruce undergrowth was good. Symptoms of oppression were mild. Spruce undergrowth grew well. Fatalities young spruce were marked only in birch forest with undergrowth of thick spruce. Thus, the reforestation direction was determined by the number of spruce undergrowth, which was stored in the timber harvesting.

In previous research, reforestation in the Southern Urals was studied (Ivanova, 2014; Maiti et al., 2016). For the western low mountains of Southern Urals the dynamics of the population structure of Picea obovata during the formation of short-term secondary birch forests, long-term secondary birch forests, and stable-term secondary aspen forests was analyzed. Similar results, such as for the Middle Urals were obtained. In short-term secondary birch forests, the initial recovery-age shifts of the emergence of new generations of Picea obovata were completely suppressed. In the formation of tree communities, only preliminary generation of Picea obovata was involved. At later stages of recovery and age, shifts restored the ability to form new generations of coniferous species, multilayers of tree stands, and age differences in undergrowth, but failures in regeneration remained (Ivanova, 2014). In the long-term secondary birch forest (throughout their formation) the age structure of spruce populations was severely impaired: new generations of Picea obovata appeared unstable, in most cases only a few were marked as numerically small generations. Picea obovata, located in the main layer of the tree stand acted as a source of semination. The restoration of conifer species tree stand dominance was greatly retarded and was possible only after the natural decay of birch over 120 years of age (Ivanova, 2014). These results were in good agreement with literature data (Pobedinskii, 1966; Isayeva, Lougansky, 1981; Sannikov, 1992).

\section{Conclusion}

Timber harvesting causes appearance of a set of vegetation communities within a single habitat (one indigenous forests type). For a long time these communities differ sharply by the structure of all vegetation layers. They differ by the direction and intensity of restoration processes. The results of this research are fundamental to understanding the evolution of modern ecosystems under anthropogenic impact and climate change.

\section{References}

Achard, F., Frederic, A., Danilo, M., Stibig, H.J., Aksenov, D., Laestadius, L., Zengyuan, L., Popatov, P., Yaroshenko, F., 2006. Areas of rapid forest-cover change in boreal Eurasia. Forest Ecology and Management 237(1-3), 322-334.

Chen, I.C., Hill, J.K., Ohlemuller, R., Roy, D.B., Thomas, C.D., 2011. Rapid range shifts of species associated with high levels of climate warming. Science 333, 1024-1026.

Cusack, D.F., Karpman, J., Ashdown, D., Cao, Q., Ciochina, M., Sarah, H., Lydon, S., Neupane, A., 2016. Global change effects on humid tropical forests: Evidence for biogeochemical and biodiversity shifts at an ecosystem scale. Reviews of Geophysics 54 (3), 523-610. https:// doi.org/10.1002/2015rg000510

Davidychev, A.N., Kulagin, A.Y., Gorichev, Y.P., 2006. Natural renewal dark coniferous forests of Southern Urals 
Mountains (on an example of the South Ural state natural reserve). Forestry Bulletin 3, 46-54.

Firsova, V.P., 1977. Soils in the taiga zone of the Ural and Trans-Ural regions. Moscow: The Science, 176.

Fisichelli, N.A., Frelich, L.E., Reich, P.B., 2014. Temperate tree expansion into adjacent boreal forest patches facilitated by warmer temperatures. Ecography 37 (2), 152-161. DOI: 10.1111/j.1600-0587.2013.00197.x

Fitzsimmons, M., 2003. Effects of deforestation and reforestation on landscape spatial structure in boreal Saskatchewan, Canada. Forest Ecology and Management 174(1-3), 577-592. DOI: 10.1016/S03781127(02)00067-1.

Foley, J.A., DeFries, R., Asner, G.P., Barford, C. , Bonan, C., Carpenter, S.C., Coe, M.T., Daily, G.C., Gibbs, H.K., Helkowski , J.H., Holloway, T., Howard, E.A., Kucharik C.J., Monfreda, C., Patz, J.A., Prentice, C., Ramankutty, N., Snyder , P.C., 2005. Global consequences of land use. Science 309, 570-574. DOI: 10.1126/science.1111772

Forest Communities Study Methods, 2002. St. Petersburg: Chemistry R\&D Institute of St. Petersburg State University, 240.

Gauthier, S., Bernier, P., Kuuluvainen, T., Shvidenko, A.Z., Schepaschenko, D.G., 2015. Boreal forest health and global change. Science 349 (6250), 819-822. DOI: 10.1126/science.aaa9092

Gray, L.K., Hamann, A., 2011. Strategies for reforestation under uncertain future climates: Guidelines for Alberta, Canada. PLOS ONE 8. DOI: 10.1371/journal. pone.0022977.

Ibbe, M., Milberg, P., Tuner, A., Bergman, K.O., 2011. History matters: Impact of historical land use on butterfly diversity in clear-cuts in a boreal landscape. Forest Ecology and Management 11(261), 1885-1891. DOI: 10.1016/j.foreco.2011.02.011.

Isaeva, R.P., Lougansky, N.A., 1981. Forest regeneration in Urals Mountains. Forest husbandry (Lesnoe hoziaistvo) 10, 38-40.

Ivanova, N.S., 2000. Classification methods of the Southern Urals mountain forests, Forestry (Lesovedenie) 4, 16-21.

Ivanova, N.S., 2012a. Divergence and Convergence of Forest Vegetation in the Urals. Scientific enquiry in the contemporary world: theoretical basics and innovative approach. FL, USA, L\&L Publishing, 59-63.

Ivanova, N.S., 2012b. Forests types of the Western low mountains of the Southern Urals. News of the Samara scientific center of the Russian Academy of Sciences (Izvestiya Samarskogo nauchnogo tsentra RAN) 1, 1020-1023.
Ivanova, N.S., 2014. Differentiation of forest vegetation after clear-cuttings in the Ural mountains. Modern Applied Science 8(6), 195-203.

Ivanova, N.S., Novogorodova, G.G., Chetkina, E.S., 2000. Tendencies of Anthropogenic Dynamics of Vegetation and Soil in Montaineous Dark-Coniferous Forests of the Ural region. Biodiversity and Dynamics of Ecosystems in North Euraia. Volume 4: Forest and soil ecosystems of north Eurasia. Russian Academy of Scieces Siberian Branch, Novosibirsk, 58-60.

Ivanova, N.S., Zolotova, E.S., 2011. Vegetation and soil differentiation within the limits of ecotope on the Middle Ural region. European Journal of Natural History 1, 44-46.

Ivanova, N.S., Zolotova, E.S., 2013a. Biodiversity of the natural forests in the Zauralsky hilly piedmont province. Modern problems of education and science (Sovremenniye problemy nauki i obrazovanija) 1. Available from http://www.science-education.ru/1078563.

Ivanova, N.S., Zolotova, E.S., 2013b. Model of forest restoration. Population Dynamics: Analysis, Modelling, Forecast 2, 50-60.

Ivanova, N.S., Zolotova, E.S., 2014. Development of Forest Typology in Russia. International Journal of Bioresource and Stress Management 5(2), 298-303.

Ivanova, N.S., Zolotova, E.S., 2015. Ecological space of forest type in the montains of Middle Urals. Modern problems of education and science (Sovremenniye problemy nauki i obrazovanija) 3. Available from http:// www.science-education.ru/123-19372. DOI 10.17513/ spno.123-19372

Kolesnikov, B.P., Zubareva, R.S., Smolonogov, E.P., 1973. Forest vegetation conditions and forest types of the Sverdlovsk region. UNTS of Academy of science of the USSR, Sverdlovsk, 176.

Kuuluvainen, T., 2016. Ecosystem Management of the Boreal Forest. Oxford Research Encyclopedia of Environmental Science. https://doi.org/10.1093/ acrefore/9780199389414.013.15

Lankin, Y.P., Ivanova, N.S., 2015. Methodological problems in the modeling of ecosystems and ways of solutions. International Journal of Bio-resource and Stress Management 6(5), 631-638.

Maiti, R., Rodriguez, H.G., Ivanova, N.S., 2016. Autoecology and Ecophysiology of Woody Shrubs and Trees: Concepts and Applications. John Wiley \& Sons, 352.

Melechov, I.S., 1933. About fur-tree renewal on slash fire. Forest husbandry and forest exploitation (Lesnoe hoziastvo i lesoekcpluatacia) 10, 30-32. 
Noss, R.F., 1999. Assessing and monitoring forest biodiversity. Forest Ecology and Management 115, 135-146.

Pavlov, D.S., Striganova, B.R., Bukvareva, E.N., 2010. An environment-oriented concept of nature use. Herald of the Russian Academy of Sciences 80(1), 74-82.

Pobedinsky, A.V., 1966. The studying of forest regeneration process. Moscow: The Science, 64.

Sannikov, S.N., 1992. Ecology and geography of natural renewal of a pine ordinary. Moscow. The Science, 264

Sannikov, S.N., Sannikova, N.S., Petrova, I.V., 2004. Natural Forest Regeneration in Western Siberia (an ekologogeographical sketch). Publishing house of The Ural branch of Russian Academy, Yekaterinburg, 198.

Shirokikh, P.S., Martynenko, V.B., Kunafin, A.M., 2013. Experience in syntaxonomic and ordination analysis of progressive succession in cutover areas of boreal light conifer forests in the Southern Urals. Russian Journal of Ecology 44(3), 185-192.

Thomasius, H., 1990. Vorkommen, Bedeutung und Bewirtschaftung der Fichte in der DDR Forstwissenschaftlichen Centralblatt 109, 138-151.
Westgate, M.J., Likens, G.E., Lindenmayer, D.B., 2013. Adaptive management of biological systems: a review. Biological Conservation 158, 128-139.

Young, J.E., Sanchez-Azofeifa, A., Hannon, S.J., Chapman, R., 2006. Trends in land cover change and isolation of protected areas at the interface of the southern boreal mixed wood and aspen parkland in Alberta, Canada. Forest Ecology and Management 230(1-3), 151-161.

Zobel, M., 2016. The species pool concept as a framework for studying patterns of plant diversity. Journal of Vegetation Science 27, 8-18.

Zolotova, E.S., 2013. Typological Features of Vegetation and Soils in Zauralsky hilly Piedmont Province: Dissertation of Candidate of Biology: 06.03.02. Zolotova Ekaterina. Ekaterinburg, 208.

Zubareva, R.S., Firsova, V.P., 1963. On Soil Characteristics in Spruce Forests of the Mountain Band in the Middle Ural Region. Soils and Hydrologic Regime of Ural forests (Problems of forestry development in the Ural region). UF AN SSSR, Sverdlovsk, 5-27. 